\title{
The influence of the heat treatment on mechanical and microstructure properties of Fe-Mn-C high-manganese steel
}

\author{
Y. Akinay*, F. Hayat \\ Metallurgical and Materials Engineering Department, Engineering Faculty, Karabük University, Demir Çelik Campus, \\ 78050 Karabük, Turkey
}

Received 24 February 2015, received in revised form 2 May 2015, accepted 11 May 2015

\begin{abstract}
The influence of the heat treatment on mechanical properties and microstructures of the Fe-22Mn-0.6C high-manganese steel was investigated at different annealing temperatures. A high-Mn TWIP (Twinning Induced Plasticity) steel specimens (0.6C, 24Mn steel) were fabricated, and were annealed at 700,900 , and $1100^{\circ} \mathrm{C}$ for $150 \mathrm{~min}$ and then air-cooled. The carbide precipitates in the microstructure of specimens were annealed at $700{ }^{\circ} \mathrm{C}$. However, the microstructure of specimens annealed at 900 and $1100{ }^{\circ} \mathrm{C}$ is austenite and some grains include annealing and mechanical twins. The results show that tensile strength of the material decreased, and the ductility of material was improved with increasing annealing temperature. Besides that, hardness value decreased between 700 and $1100^{\circ} \mathrm{C}$, which shows a good agreement with the equilibrium dissolution temperature of $\mathrm{M}_{3} \mathrm{C}$ carbides.
\end{abstract}

K e y words: high-manganese steel, heat treatment, SEM, cold rolling, TWIP steel, microstructure

\section{Introduction}

Economic and environmental considerations are constantly driving the automotive industry to form unique designs and material combinations for both weight reduction and structural integrity [1-3]. With the increasing of competition every passing day, changing product portfolio and a variety of materials used in the automotive industry have led to different investigations. Besides, the automotive industry at the top of the primary sectors has been affected by the energy and financial crises in the last three or four decades [4]. Also the fuel oil prices, which were on a stable price tariff until the 1970s, have begun to show a rapid and fluctuating increase since those years. Therefore, studies have focused on manufacturing lighter vehicles by using steel types that can meet the strength needs on different parts of an automobile in the best way without reducing the strength $[5,6]$.

The automotive industry is one of the industries most affected by the energy, oil, environmental factor (reduction of the emission of $\mathrm{CO}_{2}$ gas) and financial crises experienced in recent years. The re- duction of fuel consumption and $\mathrm{CO}_{2}$ emissions is one of the most important challenges facing the automotive industry. The fluctuations experienced in fuel prices in the last 30-40 years due to crises have compelled countries to take economic precautions [7]. For this reason, there is a significant increase in using light metals such as aluminium alloys, magnesium alloys, IF (Interstitial-Free) steel, BH (Bake Hardening) steel, DP (Dual Phase), TRIP (Transformation Induced Plasticity) steels and TWIP (Twinning Induced Plasticity) steels [8-12].

The rise in the oil prices plays a major role in the automotive industry. In the next few years, fuel consumption and new anti-pollution standards are the most important subjects for the automotive industry. For this reason, the weight reduction is demanded for automotive industry $[13,14]$. The development of steels for automotive applications is focused on improvement of ductility [15]. However, structural components and body parts of automobile are subjected to demands for decreased weight. An extraordinary combination of ductility and strength can be obtained in high manganese Twinning Induced Plasticity (TWIP)

*Corresponding author: tel.: 00905445535917; fax: 00903704338832; e-mail address: yukselakinay@karabuk.edu.tr 
Table 1. The chemical composition of test specimens (wt.\%)

\begin{tabular}{ccccccccccc}
\hline $\mathrm{Mn}$ & $\mathrm{Si}$ & $\mathrm{Cr}$ & $\mathrm{C}$ & $\mathrm{P}$ & $\mathrm{S}$ & $\mathrm{Cu}$ & $\mathrm{Al}$ & $\mathrm{Co}$ & $\mathrm{Fe}$ \\
\hline 24 & 0.626 & 0.1 & 0.582 & $<0.03$ & $<0.005$ & 0.1 & 0.002 & 0.16 & balanced \\
\hline
\end{tabular}

steels, where mechanical twinning proceeds gradually during deformation of the material [16]. For this reason, twinning induced plasticity (TWIP) steels have attracted much interest thanks to their extraordinary ductility and high strength properties for an application to automotive industry. From this point, automotive industries focus on to reduce weight of vehicles by using advanced high-strength steels (AHSS) such as twinning induced plasticity (TWIP) steels [17-19].

TWIP steels have a high manganese content that causes the steel to be fully austenitic structure. However, TWIP steel has an austenite structure at room temperature with high Mn additions. Three types of high-manganese TWIP steel, Fe-Mn-C, Fe-Mn-C-Al, and Fe-Mn-Si-Al, have been extensively investigated until now [20-26]. During plastic deformation by hot and cold rolling, TWIP steel contains mechanical twins. Twins are formed inside austenite grains by deformation, and these twins play an important role in mechanical properties such as high strength and elongation [27]. The deformation mechanism of FCC materials is related to stacking fault energy (SFE), which is determined by the chemical composition and the deformation temperature [28, 29].

Mechanical twinning occurs at stacking fault energies roughly $18<\mathrm{SFE}<24 \mathrm{~mJ} \mathrm{~m}^{-2}$, the transformation of austenite to martensite happens in $12<\mathrm{SFE}<$ $18 \mathrm{~mJ} \mathrm{~m}^{-2}$. Chemical composition, temperature, and grain size affect the $\mathrm{SFE}[30,31]$. For instance, $\mathrm{Al}$ greatly increases the SFE in TWIP steels [32].

Apart from twins, the carbide precipitates and grain size also affect the mechanical properties of TWIP steel $[32,33]$. In high-Mn steel, carbide forms are such as $\mathrm{M}_{3} \mathrm{C}\left((\mathrm{Fe}, \mathrm{Mn}, \mathrm{Cr})_{3} \mathrm{C}\right)$ in the high temperature. Kang, S. et al. (2010) concluded that in their study, the reversion of the tensile strength occurred between 700 and $800^{\circ} \mathrm{C}$ because of the carbide precipitation hardening [32]. However, Hayat, F. and Akinay, $\mathrm{Y}$. also reported that, although the carbide precipitates occurred at $700^{\circ} \mathrm{C}$, instead of them, the twins were observed at 800 and $900^{\circ} \mathrm{C}$ [33]. According to some reports, the high incidence of carbide precipitation was seen in the high-Mn and medium-C alloys such as Fe-22Mn-0.6C TWIP steel [32, 34]. Therefore, mechanical properties of TWIP steels not only depend on twins but also depend on grain size and carbide precipitation.

In this study, the influence of annealing temperature and annealing time on the mechanical properties and microstructure of Fe-24Mn-0.6C TWIP steel are investigated. However, the formation of twinning and dissolution of carbides also are investigated by increasing of annealing temperature.

\section{Experimental}

The high-manganese TWIP steel was used in this study and chemical composition of the studied TWIP steels is presented in Table 1. Test specimens were melted by induction melting in a vacuum furnace cast as bars of $70 \mathrm{~mm} \times 95 \mathrm{~mm} \times 400 \mathrm{~mm}$. These bars were homogenized at $1200^{\circ} \mathrm{C}$ for $6 \mathrm{~h}$ and hot-rolled to a plate $6 \mathrm{~mm}$ thick at the temperatures between 1100 and $1000^{\circ} \mathrm{C}$. After hot rolling the specimens were $\% 30$ cold rolled to $3 \mathrm{~mm}$ thickness. The heat treatment was carried out at 700,900 , and $1100^{\circ} \mathrm{C}$ for $150 \mathrm{~min}$ and air-cooling applied for all specimens.

After annealing the specimens were ground and polished for a field emission scanning electron microscope (FESEM) Carl Zeiss Ultra Plus machine. The fracture zone of specimens also was observed using a field emission scanning electron microscope (FESEM) Carl Zeiss Ultra Plus machine. The SEM observation and multi-point EDX analyses of the specimen were carried out at $10 \mathrm{kV}$ acceleration voltage and a working distance of $9 \mathrm{~mm}$ by FESEM with an energy-dispersive X-Ray spectroscopy (EDX) analysis system. To examine the mechanical properties of specimens, tensile tests were carried out at room temperature at a crosshead speed of $2 \mathrm{~mm} \mathrm{~min}^{-1}$ by an MTS (100kN Servohydraulic) test machine. Hardness measurement was performed using Vickers hardness (HV 0.5) Qness hardness measurement device.

\section{Results and discussion}

\subsection{SEM and EDX analysis}

Figure 1 shows the microstructure of specimens annealed at 700,900 , and $1100{ }^{\circ} \mathrm{C}$ for $150 \mathrm{~min}$. The microstructure of specimens annealed at 900 and $1100^{\circ} \mathrm{C}$ is fully austenitic (Figs. 1b,c), and some grains are including twins. The microstructure of specimen annealed at $700^{\circ} \mathrm{C}$ is including carbide precipitates and it is also seen that the recrystallized areas do not contain any mechanical twins (Fig. 1a). Besides that, the samples annealed at 900 and $1100{ }^{\circ} \mathrm{C}$ do not include carbide precipitates. This is in good agreement with 

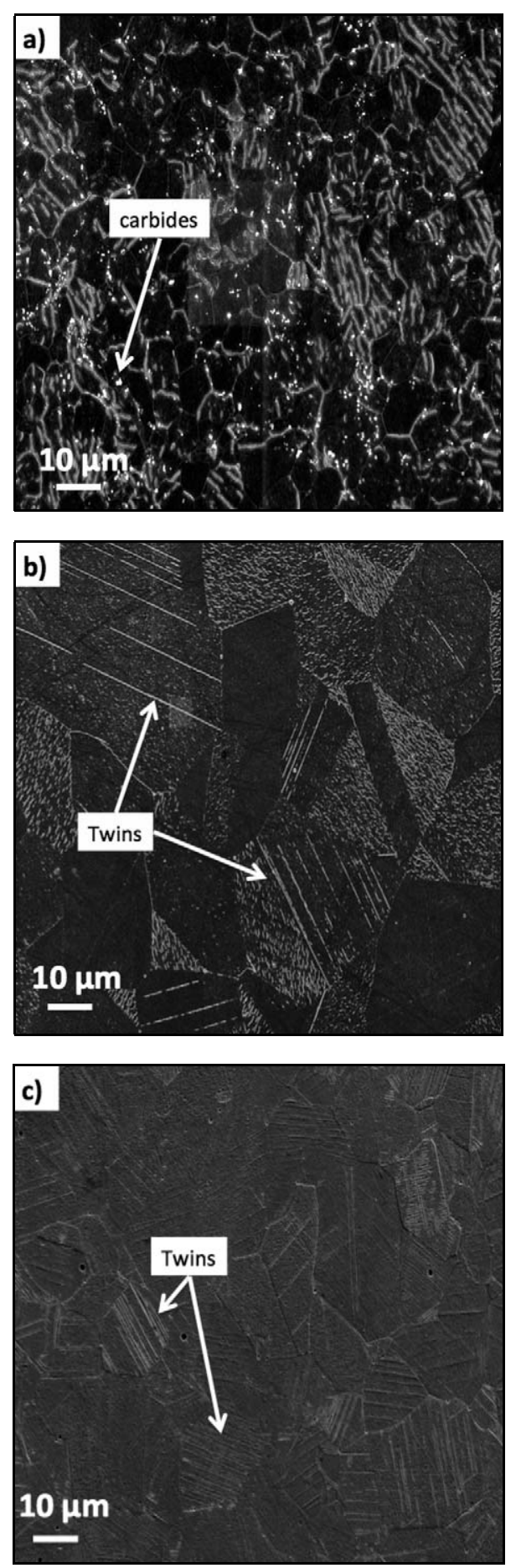

Fig. 1. SEM micrographs of the specimens annealed at (a) $700{ }^{\circ} \mathrm{C}$, (b) $900{ }^{\circ} \mathrm{C}$, (c) $1100^{\circ} \mathrm{C}$ for $150 \mathrm{~min} ; \% 50$ cold-rolled Fe-24Mn-0.6C high-manganese steel.

the equilibrium dissolution temperature of $\mathrm{M}_{3} \mathrm{C}$ carbide precipitates. Ueji, R. et al. (2008) have reported that all the samples annealed above $700{ }^{\circ} \mathrm{C}$ show fully recrystallized structures and most of the recrystallized grains include a few annealing twins [35]. Furthermore, the density of twinning increased with increasing an-

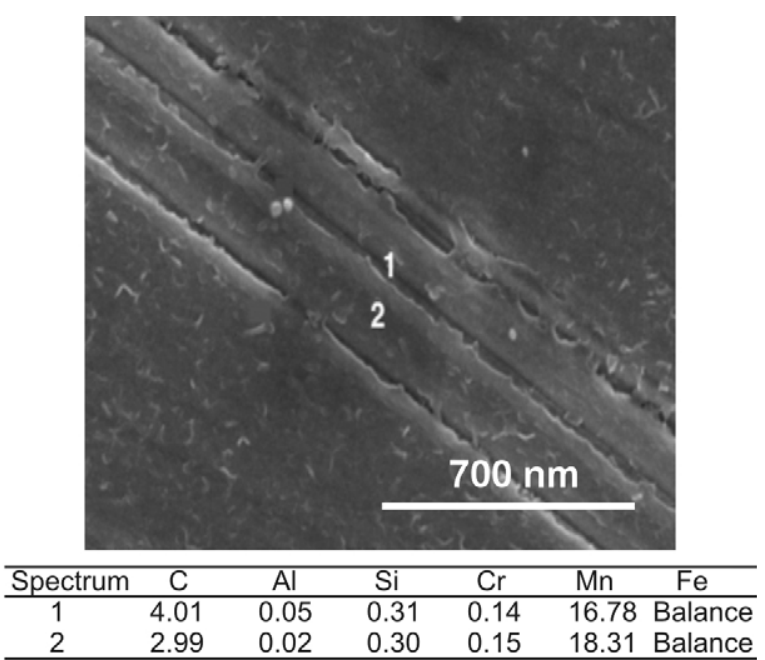

Fig. 2. Multi Point EDX result of specimen annealed at $900^{\circ} \mathrm{C}$.

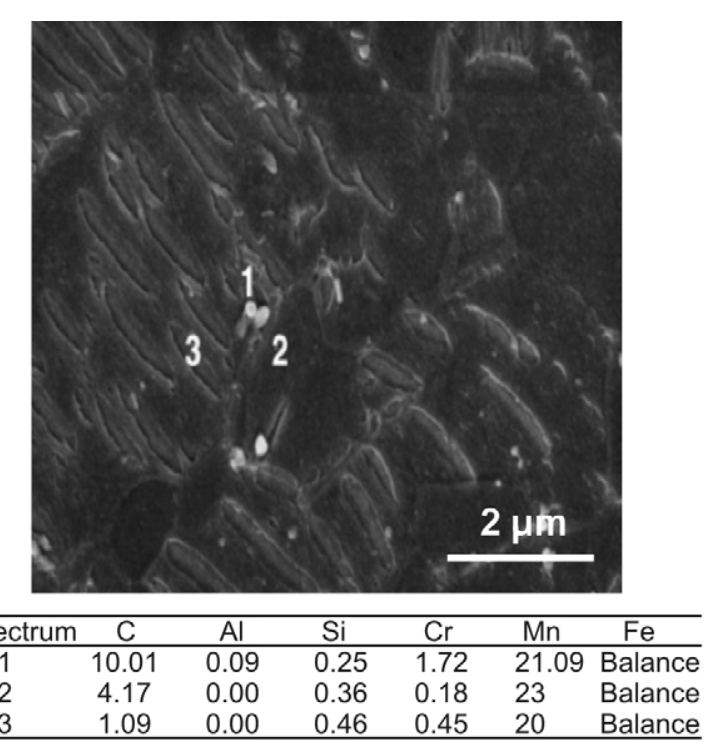

Fig. 3. Multi Point EDX result of specimen annealed at $700^{\circ} \mathrm{C}$.

nealing temperature. It can be seen obviously in Fig. 1. The specimen annealed at $1100^{\circ} \mathrm{C}$ has more twins than the specimen annealed at $900^{\circ} \mathrm{C}$. The specimen annealed at $700^{\circ} \mathrm{C}$ does not include twins. Therefore, it can be concluded that the carbide precipitation delayed the recrystallization during annealing and prevented the formation of twins [36].

The multi-point EDX analysis of cold-rolled specimens is given in Figs. 2, 3. The EDX analysis of specimen annealed at $700^{\circ} \mathrm{C}$ shows that the $\mathrm{M}_{3} \mathrm{C}$ precipitates contain a high proportion of carbon and chrome. EDX results show that the amount of $\mathrm{Mn}$ and $\mathrm{Cr}$ also increased from 24 to $31.09 \%$ and from 0.09 to $1.72 \%$ 
Table 2. Tensile strength of test specimens annealed at 700,900 , and $1100^{\circ} \mathrm{C}$

\begin{tabular}{cccc}
\hline Annealing temperature $\left({ }^{\circ} \mathrm{C}\right)$ & Yield strength $(\mathrm{MPa})$ & Ultimate tensile strength $(\mathrm{MPa})$ & Elongation $(\%)$ \\
\hline 0 & 1191 & 1597 & 2 \\
700 & 445 & 871 & 28 \\
900 & 283.7 & 764.8 & 50 \\
1100 & 189.3 & 589.5 & 63 \\
\hline
\end{tabular}

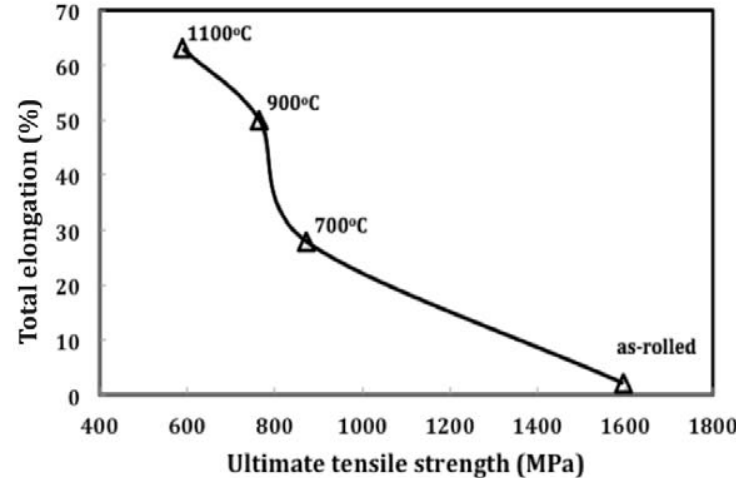

Fig. 4. The effect of annealing temperature on ultimate tensile stress - total elongation balance of samples.

respectively on precipitates (Fig. 3). This is an evidence of $\mathrm{Mn}_{3} \mathrm{C}$ and $\mathrm{Cr}_{3} \mathrm{C}$ precipitates.

\subsection{Tensile and hardness results}

The effects of cold rolling reduction and annealing temperature on the tensile deformation behaviour of all samples are listed in Table 2, and tensile strength results are an average of three cold-rolled specimens for each annealed group. For comparison, the mechanical properties such as the ultimate tensile strength (UTS) and total elongation (TEL) are presented in Fig. 4. It is observed that the specimen annealed at $700^{\circ} \mathrm{C}$ has higher UTS and yield strength (YS) than the specimen annealed at 900 and $1100^{\circ} \mathrm{C}$. Moreover, the TEL of annealed specimens increases with increasing annealing temperature. As a general rule, the values of YS and UTS of all specimens decrease with increasing annealing temperature while the values of TEL increase. The slight decrease in the values of YS and UTS may be attributed to the microstructural changes. The SEM images of specimen annealed at $700^{\circ} \mathrm{C}$ include carbide precipitates (Fig. 1a). The results show that formation of precipitates in specimen annealed at $700{ }^{\circ} \mathrm{C}$ leads to an increase in the instantaneous UTS (Stress) and TEL (Strain) because $\mathrm{M}_{3} \mathrm{C}$ carbides lead to additional strain hardening in the tensile specimens. The carbide particles not only delayed the recrystallization but also contributed to the precipitation hardening during annealing resulting in an additional increase in yield strength of TWIP steels [36].
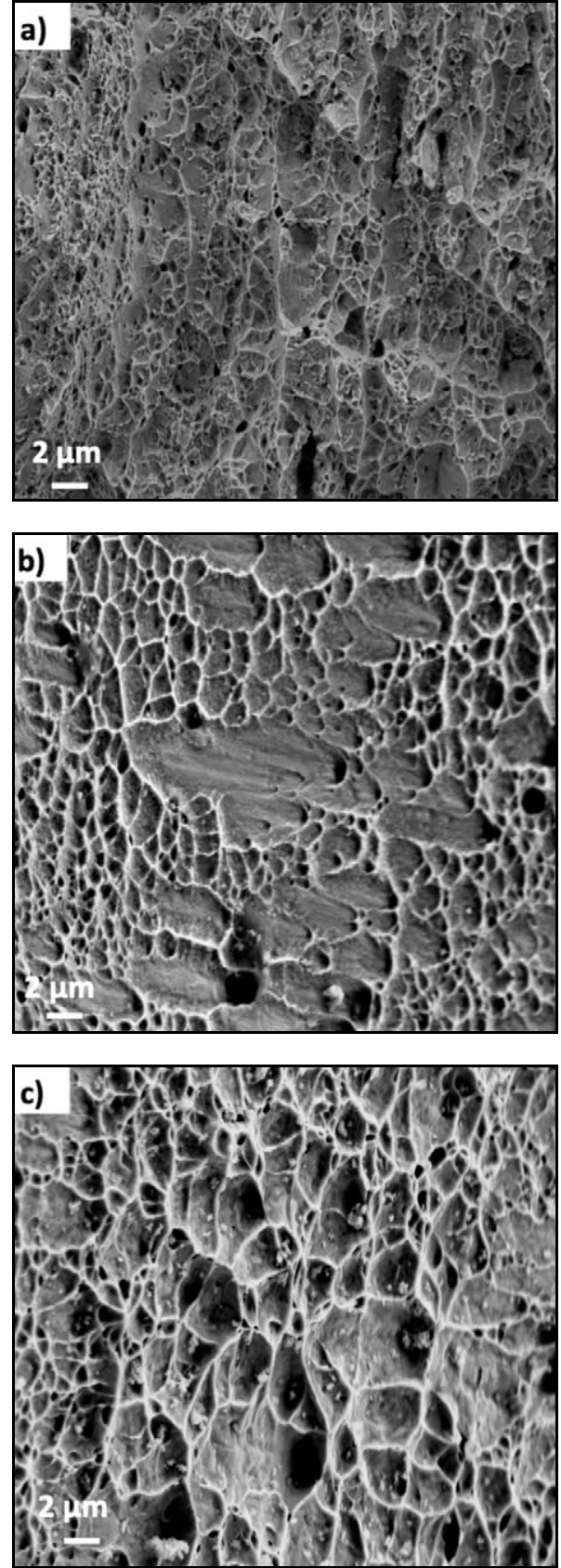

Fig. 5. SEM micrographs of the fracture surface of specimens annealed at (a) $700{ }^{\circ} \mathrm{C}$, (b) $900{ }^{\circ} \mathrm{C}$, and (c) $1100^{\circ} \mathrm{C}$ for $150 \mathrm{~min}$; \%50 cold-rolled Fe-24Mn-0.6C high-manganese steel. 


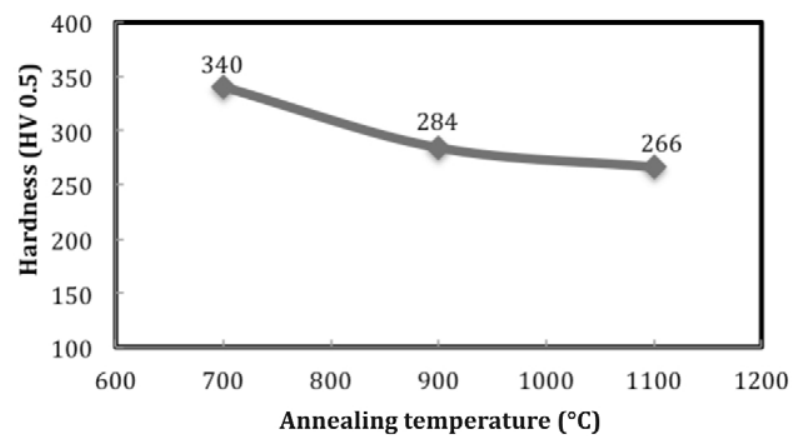

Fig. 6. Vickers hardness values of specimens annealed at $700,900,1100{ }^{\circ} \mathrm{C}$ and of as-rolled specimen.

The SEM image of fracture zone of specimens annealed at 700, 900, and $1100^{\circ} \mathrm{C}$ is given in Fig. 5. The specimens annealed at 900 and $1100^{\circ} \mathrm{C}$ exhibit ductile fracture, but the ductile fractures decreased at $700^{\circ} \mathrm{C}$ and brittle fracture areas can be seen at $700{ }^{\circ} \mathrm{C}$ (Fig. 5a). At 900 and $1100^{\circ} \mathrm{C}$, the character of the fracture is ductile as can be seen from the existence of dimples having various sizes, as shown in Fig. 5 . Hamada, A. S. et al. (2010) reported that the cracks got distorted into elongated voids until final failure showed the flat grain surfaces with shallow dimples [37].

Vickers hardness values of specimens annealed at 700,900 , and $1100^{\circ} \mathrm{C}$ are given in Fig. 6. The hardness value of the annealed specimen at $700^{\circ} \mathrm{C}$ is higher than that of the annealed specimen at 900 and $1100^{\circ} \mathrm{C}$. This is due to the formation of the carbide precipitates at $700^{\circ} \mathrm{C}$. Besides that, a decrease in hardness value is seen between 900 and $1100^{\circ} \mathrm{C}$, which shows a good agreement with the equilibrium dissolution temperature of $\mathrm{M}_{3} \mathrm{C}$ carbides. However, as shown in SEM images, the grain size of specimens also increases with increasing annealing temperature. Kang, S. et al. (2010) conclude that the increase in the coarsening rate of the grains and the decrease in hardness of the annealed specimens is in good agreement with the equilibrium dissolution temperature of $\mathrm{M}_{3} \mathrm{C}$ carbide precipitation $[32]$.

\section{Conclusions}

The tensile and yield strength reduced, but elongation increased with increasing annealing temperature. Furthermore, the twin appearance in specimens increased with increasing annealing temperature. Carbide precipitation and annealing temperature affected the formation of twins.

The high density of the mechanical twins was observed at 900 and $1100^{\circ} \mathrm{C}$. Instead of twins carbide precipitates were observed at $700^{\circ} \mathrm{C}$. The carbide precipitation delayed the recrystallization and contributed to the precipitation hardening during annealing.

The hardness value of specimens reduced with increasing annealing temperature. The decrease in hardness of the annealed specimens between 900 and $1100^{\circ} \mathrm{C}$ is the result of the dissolution of $\mathrm{M}_{3} \mathrm{C}$ carbide. However, the dissolution of carbide precipitates increased with increasing annealed temperature.

\section{References}

[1] Li, D., Feng, Y., Song, S., Liu, Q., Bai, Q., Ren, F., Shangguan, F.: Journal of Alloys and Compounds, 618, 2015, p. 768. doi:10.1016/j.jallcom.2014.08.239

[2] Hayat, F.: Materials Science \& Engineering A, 556, 2012 , p. 834 .

doi:10.1016/j.msea.2012.07.077

[3] Milao, Y., Han, D., Yao, J., Li, F.: Materials \& Design, 31, 2010, p. 3121. doi:10.1016/j.matdes.2009.12.035

[4] Hayat, F., Uzun, H.: Journal of Iron and Steel Research International, 18, 2011, p. 65. doi:10.1016/S1006-706X(11)60106-4

[5] Hayat, F.: Materials \& Design, 32, 2011, p. 2476. doi:10.1016/j.matdes.2010.11.015

[6] Sun, D. Q., Lang, B., Sun, D. X., Li, J. B.: Materials Science \& Engineering A, 460, 2007, p. 494. doi:10.1016/j.msea.2007.01.073

[7] Jiang, J., Wang, Y., Qu, J., Du, Z., Sun, Y., Luo, S.: Journal of Alloys and Compounds, 497, 2010, p. 62. doi:10.1016/j.jallcom.2010.02.099

[8] Hayat, F.: Journal of Iron and Steel Research International, 18, 2011, p. 70. doi:10.1016/S1006-706X(12)60037-5

[9] Sevim, I., Hayat, F.: The International Journal of Advanced Manufacturing Technology, 58, 2011, p. 1043. doi:10.1007/s00170-011-3428-x

[10] Hayat, F., Demir, B., Acarer, M.: Metal Science and Heat Treatment, 49, 2007, p. 9. doi:10.1007/s11041-007-0090-x

[11] Hayat, F.: Journal of Materials Science \& Technology, 27, 2011, p. 1047. doi:10.1016/S1005-0302(11)60185-0

[12] Hayat, F.: Journal of the Faculty of Engineering and Architecture of Gazi University, 25, 2010, p. 701.

[13] Jeong, J. S., Koo, Y. M., Jeong, I. K., Kim, S. K., Kwon, S. K.: Materials Science \& Engineering A, 530, 2011, p. 128. doi:10.1016/j.msea.2011.09.060

[14] Chung, K., Ma, N., Park, T., Kim, D., Yoo, D., Kim, C.: International Journal of Plasticity, 27, 2011, p. 1485. doi:10.1016/j.ijplas.2011.01.007

[15] Abadi, M., Najafizadeh, A., Kermanpur, A., Mazaheri, Y.: International Journal of ISSI, 8, 2011, p. 1.

[16] Jin, J. E., Lee, Y. K.: Acta Materialia, 60, 2012, p. 1680. doi:10.1016/j.actamat.2011.12.004

[17] Lee, T., Koyama, M., Tsuzaki, K., Lee, Y., H., Lee, C. S.: Materials Letters, 75, 2012, p. 169. doi:10.1016/j.matlet.2012.02.012

[18] Baradaran, H., Hanzaki, A., Abedi, H., Varzaneh, S., Imandoust, A.: Materials Science \& Engineering A, 561, 2013, p. 411. doi:10.1016/j.msea.2012.10.051

[19] Hamada, A. S., Haggag, F., Porter, D.: Materials Science \& Engineering A, 558, 2012, p. 766. doi:10.1016/j.msea.2012.08.066 
[20] Chen, L., Zhao, Y., Qin, X.: Acta Metallurgica Sinica (Engl. Lett.), 26, 2013, p. 1. doi:10.1007/s40195-012-0501-X

[21] Soulami, A., Choi, K., Shen, Y., Liu, W., Sun, X., Khaleel, M.: Materials Science \& Engineering A, 528, 2011, p. 1402. doi:10.1016/j.msea.2010.10.031

[22] Bleck, W.: Characterisation of High Mn Steels by New Numerical and Experimental Tools. Aachen, Institute for Ferrous Metallurgy, RWTH Aachen University 2010.

[23] Koyama, M., Murakami, M., Ogawa, K.: Materials Transactions, 48, 2007, p. 2729. http://doi.org/10.2320/matertrans.MRA2007124

[24] Renard, K., Jacques, P. J.: Materials Science \& Engineering A, 542, 2012, p. 8. doi:10.1016/j.msea.2012.01.123

[25] Mi, Z., Tang, D., Yan, L., Guo, J.: J. Mater. Sci. Technol., 21, 2005, p. 451.

[26] Chung, K., Ahn, K., Yoo, D., Chung, K. H., Seo, M. Park, S.: International Journal of Plasticity, 27, 2011, p. 52. doi:10.1016/j.ijplas.2010.03.006

[27] Shen, Y., Qiu, C., Wang, L., Sun, X., Zhao, X., Zuo, L.: Materials Science \& Engineering A, 561, 2013, p. 329. doi:10.1016/j.msea.2012.10.020

[28] Peng, X., Zhu, D., Hu, Z., Yi, W., Liu, H., Wang, M.: Materials and Design, 45, 2013, p. 518. doi:10.1016/j.matdes.2012.09.014

[29] Chung, K., Ma, N., Park, T., Kim, D., Yoo, D., Kim, C.: International Journal of Plasticity, 27, 2011, p. 1485. doi:10.1016/j.ijplas.2011.01.007
[30] Razavi, G., Monajati, H.: International Journal of Materials and Mechanics Engineering, 1, 2012, p. 1.

[31] Urrutia, I., Raabe, D.: Acta Materialia, 60, 2012, p. 5791. doi:10.1016/j.actamat.2012.07.018

[32] Kang, S., Jung, Y., Jun, J., Lee, Y.: Materials Science and Engineering A, 527, 2010, p. 745. doi:10.1016/j.msea.2009.08.048

[33] Hayat, F., Akinay, Y.: In: Proceedings of the International Conference on Mining, Material and Metallurgical Engineering. Ottawa, Avestia Publishing, International ASET Inc. 2014, p. 149.

[34] Bouaziz, O., Allain, S., Scott, C., Cugy, P., Barbier, D.: Current Opinion in Solid State and Materials Science, 15, 2011, p. 141. doi:10.1016/j.cossms.2011.04.002

[35] Ueji, R., Tsuchida, N., Terada, D., Tsuji, N., Tanaka, Y., Takemura, A., Kunishige, K.: Scripta Materialia, 59, 2008, p. 963. doi:10.1016/j.scriptamat.2008.06.050

[36] Kang, S., Jung, J.-G., Lee, Y.-K.: Materials Transactions, 53, 2011, p. 2187. doi:10.2320/matertrans.M2012273

[37] Hamada, A. S., Karjalainen, L.: Materials Science \& Engineering A, 527, 2010, p. 5715. doi:10.1016/j.msea.2010.05.035 